Article

\title{
An Analysis of Fill Factor Loss Depending on the Temperature for the Industrial Silicon Solar Cells
}

\author{
Kwan Hong Min ${ }^{1,2}$, Taejun Kim ${ }^{3}$, Min Gu Kang ${ }^{1}$, Hee-eun Song ${ }^{1}$, Yoonmook Kang ${ }^{4}$, \\ Hae-Seok Lee ${ }^{4}$, Donghwan Kim ${ }^{2}$, Sungeun Park ${ }^{1, *}$ and Sang Hee Lee ${ }^{1, * \mathbb{D}}$ \\ 1 Photovoltaics Laboratory, Korea Institute of Energy Research, Daejeon 34129, Korea; \\ steel1217@nate.com (K.H.M.); mgkang@kier.re.kr (M.G.K.); hsong@kier.re.kr (H.-e.S.) \\ 2 Department of Materials Science and Engineering, Korea University, Seoul 02841, Korea; solar@korea.ac.kr \\ 3 Hyundai Energy Solutions, PV R\&D Center, Eumseong, Cheongju 27711, Korea; taejunkim@hyundai-es.co.kr \\ 4 Department of Energy Environment Policy and Technology, Green School, Graduate School of Korea Energy \\ and Environment, Korea University, Seoul 02841, Korea; ddang@korea.ac.kr (Y.K.); \\ lhseok@korea.ac.kr (H.-S.L.) \\ * Correspondence: separk@kier.re.kr (S.P.); aktkd88@naver.com (S.H.L.); \\ Tel.: +82-42-860-3419 (S.P.); +82-42-860-3419 (S.H.L.)
}

Received: 12 May 2020; Accepted: 3 June 2020; Published: 7 June 2020

check for updates

\begin{abstract}
Since the temperature of a photovoltaic (PV) module is not consistent as it was estimated at a standard test condition, the thermal stability of the solar cell parameters determines the temperature dependence of the PV module. Fill factor loss analysis of crystalline silicon solar cell is one of the most efficient methods to diagnose the dominant problem, accurately. In this study, the fill factor analysis method and the double-diode model of a solar cell was applied to analyze the effect of $J_{01}, J_{02}, R_{s}$, and $R_{s h}$ on the fill factor in details. The temperature dependence of the parameters was compared through the passivated emitter rear cell (PERC) of the industrial scale solar cells. As a result of analysis, PERC cells showed different temperature dependence for the fill factor loss of the $J_{01}$ and $J_{02}$ as temperatures rose. In addition, we confirmed that fill factor loss from the $J_{01}$ and $J_{02}$ at elevated temperature depends on the initial state of the solar cells. The verification of the fill factor loss analysis was conducted by comparing to the fitting results of the injection dependent-carrier lifetime.
\end{abstract}

Keywords: fill factor loss analysis; double-diode model; PERC; temperature dependence; recombination current density; parasitic resistance

\section{Introduction}

The fill factor $(F F)$, open circuit voltage $\left(V_{o c}\right)$ and short circuit current $\left(J_{s c}\right)$ of a solar cell are important parameters because they determine the maximum power that a solar cell can generate. It is well known that the fill factor of silicon solar cells is influenced by the recombination current and parasitic resistance. In order to clarify the effect of these factors on a fill factor, the double-diode model is generally used as a theoretical concept. In the double-diode model, the photo-generated current density reduces due to the saturation current densities $\left(J_{01}, J_{02}\right)$, and parasitic resistance $\left(R_{s}, R_{s h}\right)$ as the equation shows below.

$$
J=J_{p h}-J_{01}\left[\exp \left\{\frac{q\left(V+J R_{s}\right)}{n_{1} k T}\right\}-1\right]-J_{02}\left[\exp \left\{\frac{q\left(V+J R_{s}\right)}{n_{2} k T}\right\}-1\right]-\frac{\left(V+J R_{s}\right)}{R_{s h}},
$$

where $J$ is the diode circuit current density, $J_{p h}$ is the photo-generated current density, $J_{01}$ is the recombination current density in quasi-neutral region, $V$ is the diode voltage, $q$ is the elementary charge, $k$ is Boltzmann's constant, $n_{1}$ is the ideality factor for the diode $1, n_{2}$ is the ideality factor 
for the diode 2 , and $T$ is the absolute temperature. The $J_{01}$ in the equation is the information of the recombination current from the base material (quasi-neutral region) and both side surface of the solar cell. $J_{02}$ generally describes the Shockley-Read-Hall (SRH) recombination at the p-n junction (space charge region), but there are also other recombination sources such as edge recombination [1] and localized high defect region [2,3].

Analyzing the recombination and resistive loss of a solar cell from the perspective of fill factor is a very efficient method because it directly shows the gain of the conversion efficiency from the loss factor. Hence, there were some effort to extract fill factor loss at the space charge region $\left(J_{02}\right)$ by determining fill factor loss from $J_{01}\left(F F_{J 01}\right)$ and subtracting the pseudo fill factor $(p F F)$ that is not influenced by the series resistance [4,5]. Afterward, A. Khanna proposed a method to quantify the fill factor loss of silicon solar cells due to parasitic resistance as well as $J_{02}$, because there was a limitation that the shunt resistance must be extremely high to extract an exact fill factor loss due to $J_{02}$ in this method. In addition, since this approach does not need to assume $n_{2}$ value during the fitting procedure, it showed that a more accurate analysis is possible. The theoretical derivation is well described in [6].

This fill factor loss analysis was used in this experiment to investigate the source of fill factor loss depending on the elevated temperature, because the module efficiency assessed at the standard test condition $\left(\mathrm{STC}, 25^{\circ} \mathrm{C}\right.$ ) reduces at the actual operating temperature [7]. Figure 1 shows the measured PV module temperature change according to the seasonal temperature in Daejeon and Seoul of South Korea. The PV module temperature rises to $60^{\circ} \mathrm{C}$ which will highly degrade the module power when it is operating. The $V_{o c}$ reduction is well known for the main source of efficiency loss. $V_{o c}$ is a function of the saturation current $\left(I_{0}\right)$ which is strongly dependent on the temperature as it can be seen in Equations (2) and (3) [8]. Where $q$ is the elementary charge, $A$ is the area, $D$ is the diffusion constant, $n_{i}$ is the intrinsic carrier concentration, $L$ is the diffusion length, $N_{D}$ is the doping concentration, and $T$ is kelvin temperature. By extracting the fill factor loss of each parameter $\left(J_{01}, J_{02}, R_{s}\right.$, and $\left.R_{s h}\right)$, it will be able to provide an accurate diagnosis and appropriate solution to reduce the temperature dependence of the PV module.
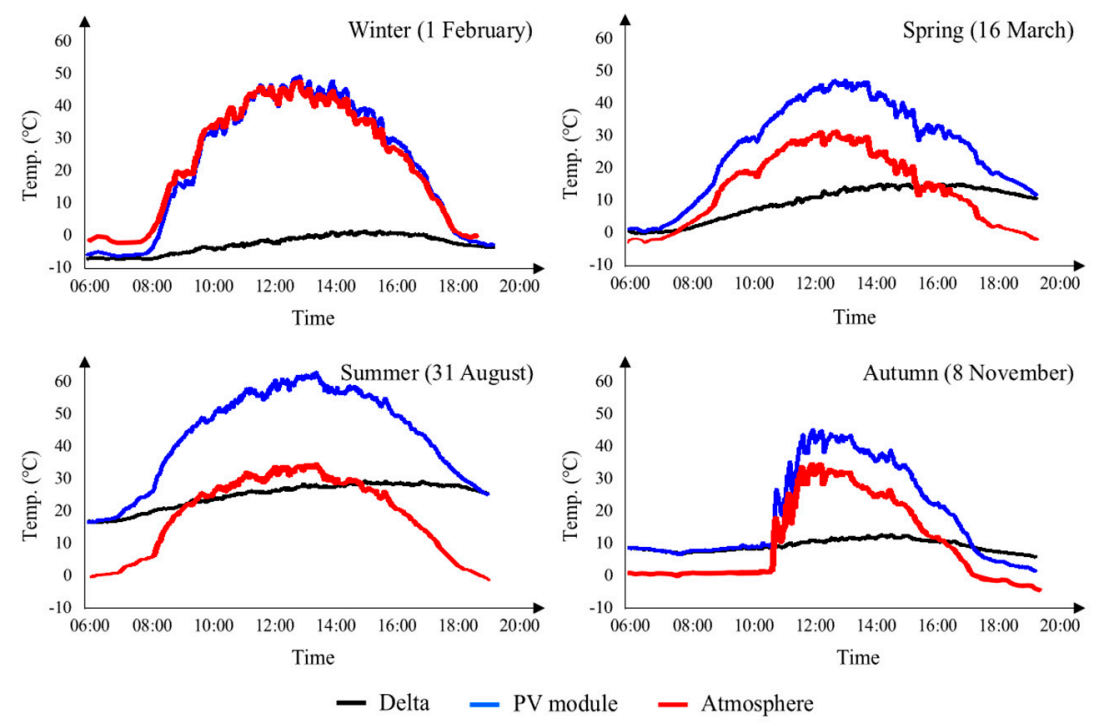

Figure 1. Photovoltaic (PV) module temperature change according to seasonal temperature.

For the analysis of fill factor loss, industrial passivated emitter and rear cell (PERC), which is leading product in PV industries, was used [9]. Many researches for optimization of both side surface passivation [10-16] and laser ablation on rear aluminum oxide $\left(\mathrm{AlO}_{\mathrm{x}}\right)$ layer $[17,18]$ for the local back surface field formation (LBSF) [19] have improved efficiency of the PERC and reached 22.8\% [20]. 
In this paper, temperature dependence of two industrial type PERC samples were compared to inspect dominant factor of fill factor loss.

$$
\begin{gathered}
I_{0}=q A \frac{D n_{i}^{2}}{L N_{D}} \\
n_{i}(T)=9.15 \times 10^{9}\left(\frac{T+273.15}{300}\right)^{2} \exp \left(\frac{-6880}{T+273.15}\right) .
\end{gathered}
$$

\section{Experimental}

\subsection{Analysis Process of Fill Factor Loss}

Figure 2 briefly summarizes the steps of the fill factor loss analysis. The analysis of the fill factor loss starts with the calculation of $F F_{j 01}$. The $F F_{j 01}$ can be determined when the effect of $J_{02}, R_{S}$ and $R_{s h}$ is absent. With this assumption, Equation (1) changes to Equation (4).

$$
J=J_{p h}-J_{01}\left[\exp \left\{\frac{q V}{n k T}\right\}-1\right] .
$$

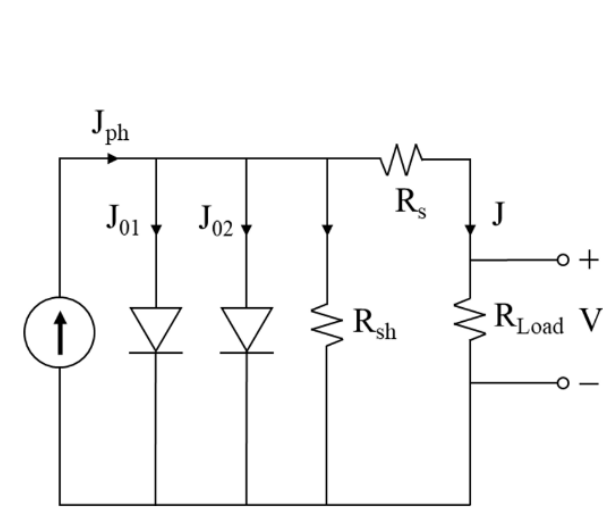

(a)

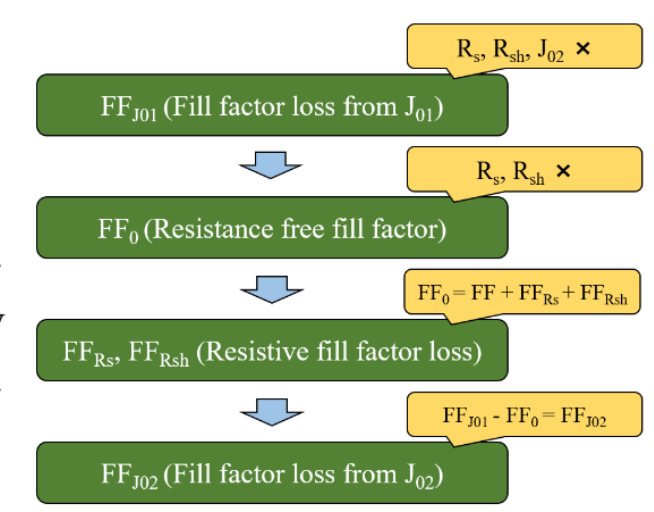

(b)

Figure 2. (a) Equivalent circuit of solar cells with double-diode model, and (b) process of fill factor loss analysis.

By imposing the boundary condition $J=0$ at $V=V_{o c}$ and $J=J_{s c}$ at $V=0$, relationship between $J$ and $V$ can be expressed in Equation (5), which $F F_{j 01}$ is allowed to be obtained.

$$
J=J_{s c}-\frac{J_{s c}}{\exp \left(\frac{q V_{o c}}{n k T}\right)-1}\left[\exp \left\{\frac{q V}{n k T}\right\}-1\right] .
$$

Afterwards, resistance free fill factor $\left(F F_{0}\right)$, which does not have loss from the parasitic resistance, is derived as in Equation (6) by considering the double-diode model at maximum power point (MPP). Where, $J_{m p p}$ and $V_{m p p}$ is the current density and voltage at power maximum point, respectively. Equation (6) is composed of three terms: real fill factor, fill factor loss from $R_{S}\left(F F_{R s}\right)$, and fill factor loss from $R_{s h}\left(F F_{R s h}\right)$, respectively from the left term.

$$
F F_{0}=F F+\frac{J_{m p p}^{2} R_{s}}{V_{o c} J_{s c}}+\frac{\left(V_{m p p}+J_{m p p} R_{s}\right)^{2}}{R_{\mathrm{sh}} V_{o c} J_{s c}} .
$$

As a last step, the fill factor loss from $J_{02}$ can be readily determined from the difference of $F F_{J 01}$ and $F F_{0}$ Equation (7), because the difference comes from the absence of the $J_{02}$ effect.

$$
F F_{J 02}=F F_{J 01}-F F_{0}
$$




\subsection{Sample Measurements with Elevated Temperature}

Two industrial solar cells with PERC structure (Figure 3) were prepared as samples (PERC A and B). The PERC A and B were fabricated on different production lines, but the front contact pattern was unified to exclude optical loss due to the front contact. In case of the PERC A, silver paste for the front contact contains higher glass frit contents compared to the PERC B. The characteristics of illuminated $J-V$ were measured by using an in-house solar simulator, which can control the temperature of substrate. Even though this fill factor analysis method assumed that $J_{01}$ follows an $n$ factor of 1 , there were changes in the $n$ factor depending on the temperature. Therefore, $n$ factor at 1 -sun, extracted from the Suns- $V_{o c}$ measurement, was used for analysis. The temperature of cells during the Suns- $V_{o c}$ measurement was controlled by using a box that has an ambient heater. The conditions of the experimental temperature were set to $25^{\circ} \mathrm{C}, 45^{\circ} \mathrm{C}$, and $65^{\circ} \mathrm{C}$.

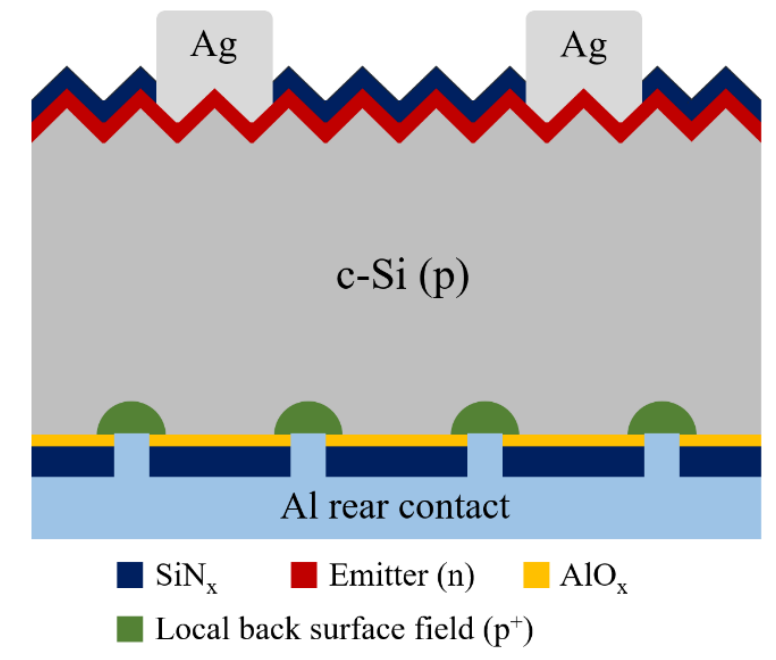

Figure 3. Schematic of the industrial PERC solar cell structure.

\section{Results and Discussion}

\subsection{Temperature Dependence}

The two PERC solar cell samples were named by the PERC A and B. As a result of the illuminated $J-V$ measurements (Table 1), $V_{o c}$ and fill factor of PERC B were $17 \mathrm{mV}$ and $1.93 \%$ higher at $25^{\circ} \mathrm{C}$, respectively. $J_{s c}$ difference was not significant $\left(\sim 1.3 \mathrm{~mA} / \mathrm{cm}^{2}\right)$ and it comes from the different fraction of front metal contact. Graphs in Figure 4 show the drop of $V_{o c}$ and fill factor (depending on temperature), and also presents the average temperature coefficient as well. The average drop of $V_{o c}$ and fill factor with the PERC A cell were slightly higher than the PERC B cell. Especially, the larger fill factor drops occurred at $45^{\circ} \mathrm{C}$ for the PERC A and $65^{\circ} \mathrm{C}$ for the PERC B. Illuminated $J-V$ measurements alone do not have enough evidence to accurately diagnose what the main problem is. 
Table 1. Results of illuminated $J-V$ measurement and $\mathrm{n}$ factor (from Suns- $V_{o c}$ ) of PERC A and B according to temperature dependence.

\begin{tabular}{ccccccc}
\hline Parameters & \multicolumn{3}{c}{ PERC A } & \multicolumn{3}{c}{ PERC B } \\
\hline Temperature $\left[{ }^{\circ} \mathrm{C}\right]$ & 25 & 45 & 65 & 25 & 45 & 65 \\
\hline$V_{o c}[\mathrm{mV}]$ & 654 & 616 & 578 & 671 & 635 & 596 \\
$J_{s c}\left[\mathrm{~mA} / \mathrm{cm}^{2}\right]$ & 38.49 & 38.74 & 39.05 & 39.79 & 40.08 & 40.21 \\
$V_{m p p}[\mathrm{mV}]$ & 564 & 517 & 478 & 580 & 526 & 494 \\
$J_{m p p}\left[\mathrm{~mA} / \mathrm{cm}^{2}\right]$ & 35.84 & 35.92 & 36.18 & 37.85 & 38.07 & 38.20 \\
$F F[\%]$ & 80.28 & 77.70 & 76.60 & 82.21 & 80.53 & 78.62 \\
$R_{s}\left[\Omega \cdot \mathrm{cm}^{2}\right]$ & 1.58 & 1.77 & 1.631 & 1.49 & 1.42 & 1.60 \\
$R_{s h}\left[\Omega \cdot \mathrm{cm}^{2}\right]$ & 10252 & 2796 & 2982 & 9553 & 26562 & 5126 \\
$\eta[\%]$ & 20.21 & 18.57 & 17.28 & 21.96 & 20.49 & 18.87 \\
$n$ factor & 1.07 & 1.14 & 1.17 & 1.05 & 1.12 & 1.19 \\
$\left(\right.$ Suns- $\left.V_{o c}\right)$ & & & & & & \\
\hline
\end{tabular}
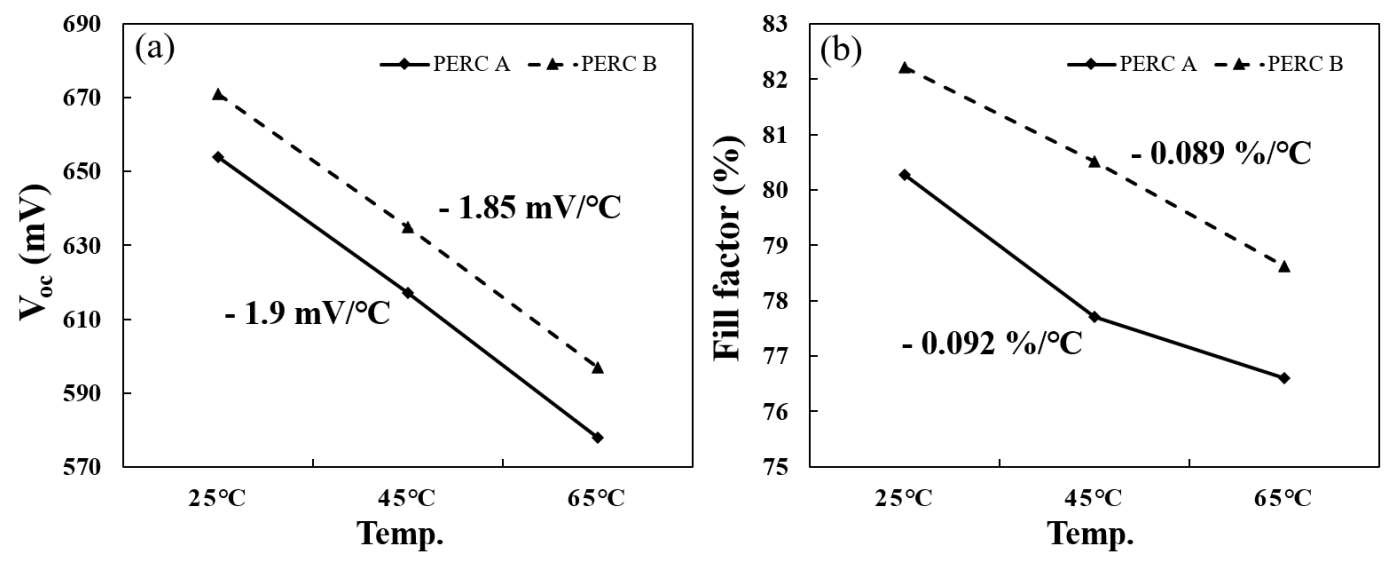

Figure 4. Temperature coefficient of (a) $V_{o c}$ and (b) fill factor.

\subsection{Results of Fill Factor Loss Analysis}

Table 2 organizes the values of each fill factor loss according to the parameters from double-diode model. From this data, Figures 5 and 6 shows the effect of each parameter on the total fill factor loss. At initial temperature, percentage of $F F_{J 01}$ was higher than $F F_{J 02}$ for the PERC B cell. On the other hand, $F F_{J 02}$ had a higher percentage of total fill factor loss than $F F_{J 01}$ for the PERC A cell. As the temperature rose, $F F_{J 01}$ ratio of both PERC A and B increased while $F F_{J 02}$ ratio decreased. This can be explained by the temperature dependence of $J_{01}$ and $J_{02}$ in Equations (8) and (9).

$$
\begin{aligned}
& J_{01}(T)=J_{01}\left(25^{\circ} \mathrm{C}\right) \times\left(\frac{n_{i}(T)}{n_{i}\left(25^{\circ} \mathrm{C}\right)}\right)^{2}, \\
& J_{02}(T)=J_{02}\left(25^{\circ} \mathrm{C}\right) \times\left(\frac{n_{i}(T)}{n_{i}\left(25^{\circ} \mathrm{C}\right)}\right) .
\end{aligned}
$$

$J_{01}$ is proportional to square of $n_{i}(T)$, which increases sensitively according to the temperature, while $J_{02}$ is directly proportional to $n_{i}(T)$. Due to the difference of the temperature dependence, the effect of $J_{01}$ becomes dominate as temperature goes up. However, the $F F_{J 02}$ ratio and the absolute value are still higher than $F F_{J 01}$ at $65^{\circ} \mathrm{C}$ for the PERC A cell. A possible explanation is that the initial value of $F F_{J 02}(1.86 \%)$ was twice higher than that of $F F_{J 01}(0.82 \%)$ and helped increase at a high temperature. 
Table 2. Results of fill factor loss analysis of PERC A and PERC B according to temperature (the values are absolute).

\begin{tabular}{ccccccc}
\hline FF Loss Analysis & \multicolumn{3}{c}{ PERC A } & \multicolumn{3}{c}{ PERC B } \\
\hline Temperature $\left[{ }^{\circ} \mathrm{C}\right]$ & 25 & 45 & 65 & 25 & 45 & 65 \\
\hline Ideal $F F[\%]$ & 83.78 & 82.89 & 82.36 & 84.08 & 83.43 & 82.67 \\
\hline Total $F F$ loss [\%] & 3.50 & 5.19 & 5.78 & 1.88 & 2.91 & 4.06 \\
\hline$F F_{J 01}[\%]$ & 0.82 & 1.70 & 2.10 & 0.58 & 1.42 & 2.30 \\
$F F_{J 02}[\%]$ & 1.86 & 2.47 & 2.69 & 0.48 & 0.70 & 0.75 \\
$F F_{R s}[\%]$ & 0.81 & 0.97 & 0.94 & 0.80 & 0.78 & 0.98 \\
$F F_{R s h}[\%]$ & 0.01 & 0.05 & 0.05 & 0.02 & 0.01 & 0.03 \\
\hline$F F_{0}[\%]$ & 81.00 & 78.72 & 77.57 & 83.02 & 81.31 & 79.62 \\
\hline Real $F F(\mathrm{LIV})[\%]$ & 80.28 & 77.70 & 76.60 & 82.21 & 80.53 & 78.62 \\
\hline
\end{tabular}
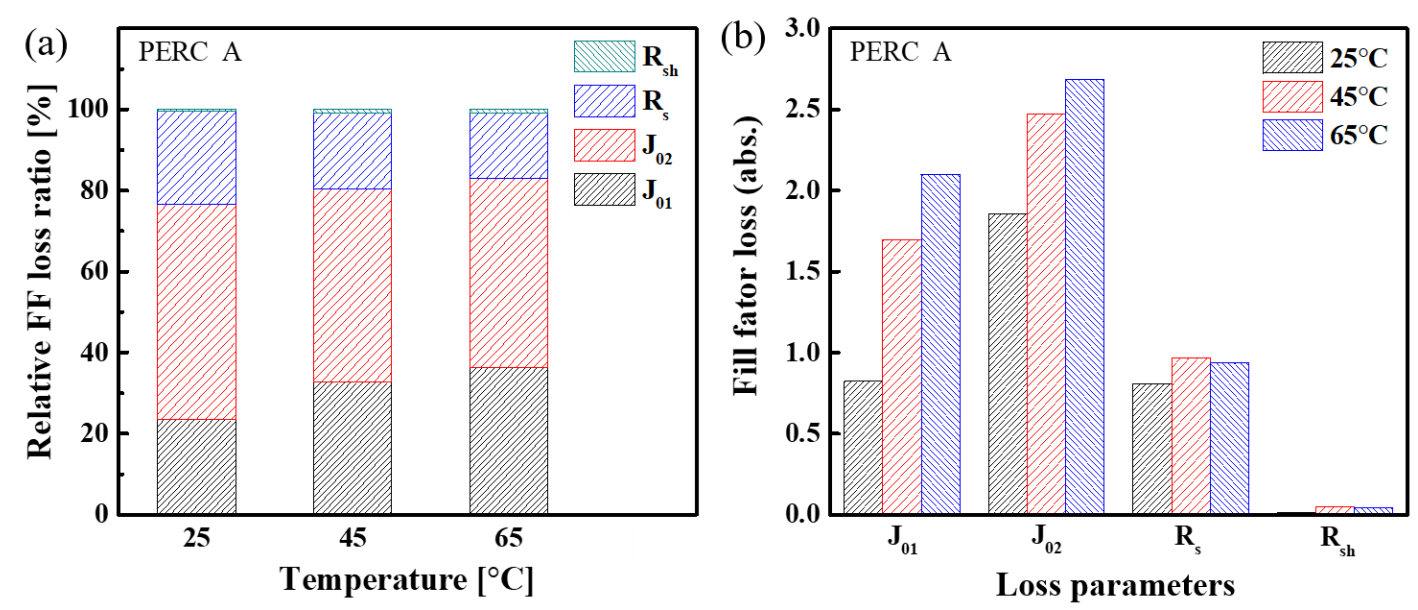

Figure 5. Fill factor loss analysis results of PERC A: (a) Normalized fill factor ratio; (b) Absolute fill factor loss.
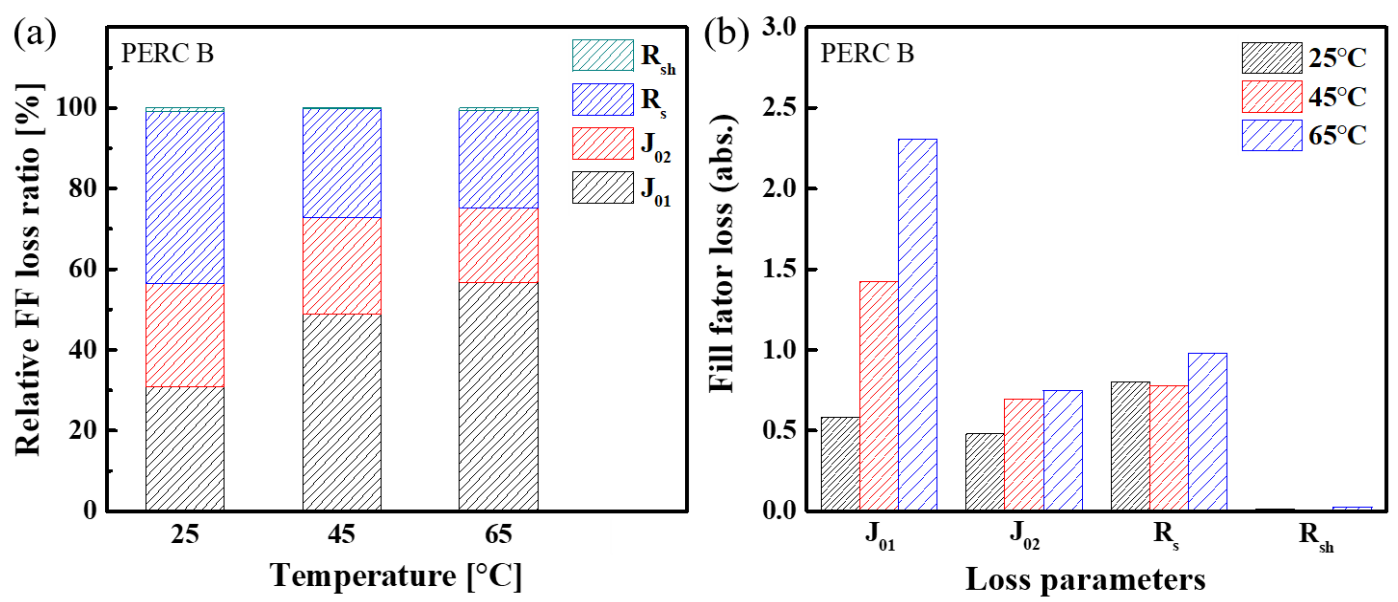

Figure 6. Fill factor loss analysis results of PERC B: (a) Normalized fill factor ratio; (b) Absolute fill factor loss.

In addition, the temperature dependence of $F F_{J 02}$ for the PERC B cell (Figure $6 \mathrm{~b}$ ) reveals that the $F F_{J 02}$ will not increase significantly at elevated temperature if the initial ratio to the total fill factor loss is relatively small. On the other hand, the difference of $F F_{J 01}$ between $25^{\circ} \mathrm{C}$ and $65^{\circ} \mathrm{C}$ increased up to 
$20 \%$, even though the initial difference was only $7 \%$. This means that the effect of $J_{01}$ on fill factor will be accelerated if the initial loss is relatively high.

In case of the PERC B cell, one can diagnose that the recombination of emitter, quasi-neutral region, or surface passivation have to be improved. Reduction of $F F_{R s}$ ratio for the PERC B cell will further reduce the temperature dependence, even though there were small variation at the elevated temperature. The ratio and temperature dependence of $F F_{R s h}$ were negligible for both PERC A and B cells.

\subsection{Verification Through Injection Dependent-Carrier Lifetime}

In order to verify the results of the fill factor loss analysis, the lifetime was measured through Sinton instrument's Suns- $V_{o c}$ equipment at $25^{\circ} \mathrm{C}$. The recombination current density of the samples was evaluated by using a lifetime fitting method. Through the specific resistance and thickness of the wafer, the Auger recombination and the radiative recombination are represented as lifetime according to the excess carrier concentration as graphs in Figure 7 show.
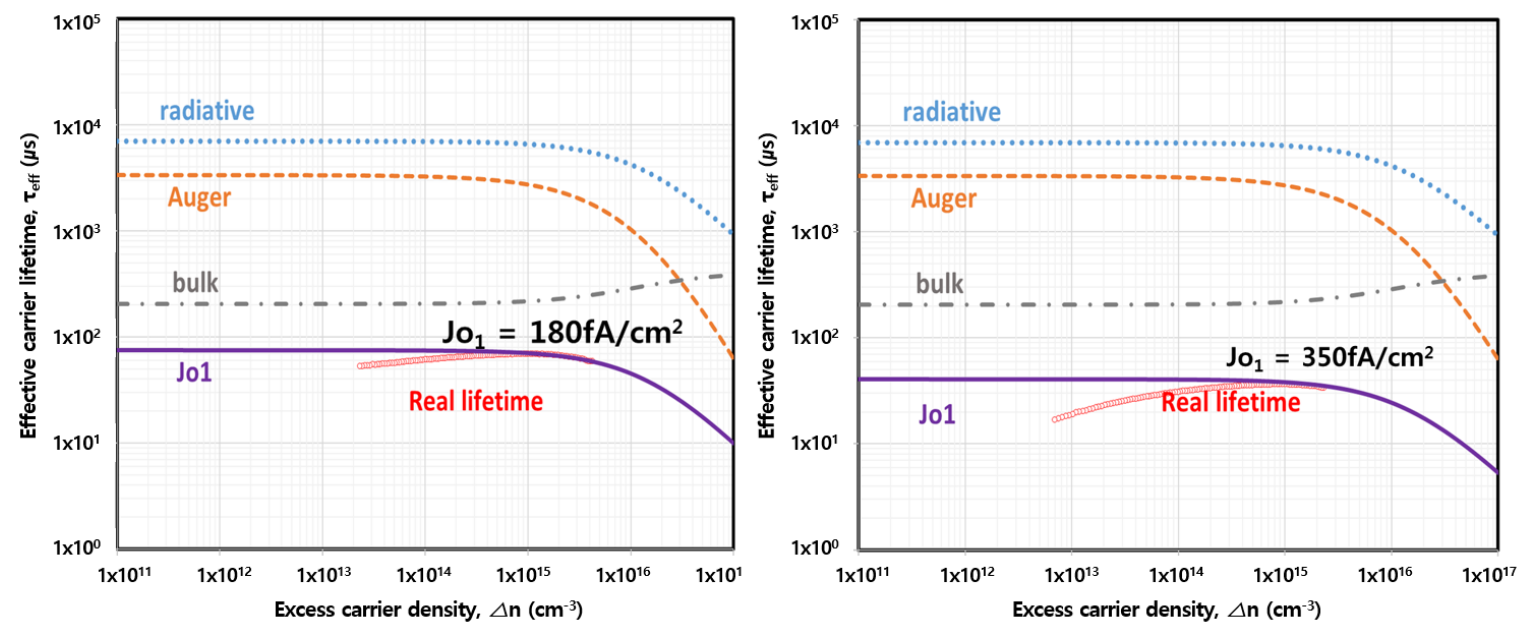

Figure 7. Fitting results of injection dependent-carrier lifetime for the PERC A (Left) and B (Right).

The expressions for the intrinsic carrier lifetime and bulk lifetime can be expressed as follows.

$$
\begin{gathered}
\tau=\frac{\Delta n}{R} \\
\frac{1}{\tau_{\text {intrinsic }+ \text { bulk }}}=\frac{1}{\tau_{\text {rad }}}+\frac{1}{\tau_{\text {Auger }}}+\frac{1}{\tau_{S R H}}
\end{gathered}
$$

Here, intrinsic recombination can be expressed as an Equation (12) [21].

$$
R_{\text {Intrinsic }}=R_{\text {Auger }}+R_{\text {Radiative }}=n p\left(1.8 \times 10^{-24} n_{0}^{0.65}+6 \times 10^{-25} p_{0}^{0.65}+3 \times 10^{-27} \Delta n^{0.8}+9.5 \times 10^{-15}\right)
$$

Where $n$ and $p$ are the free electron and hole concentrations, $n_{0}$ and $p_{0}$ are the electron and hole concentration in thermal equilibrium, and $\Delta n$ is the excess carrier densities. The bulk lifetime of a wafer can be measured with quasi-steady-state photoconductance (QSSPC) equipment. To measure the bulk lifetime of the wafer, the doped layer was removed from the wafer using $\mathrm{KOH}$ solution after $\mathrm{POCl}_{3}$ diffusion, and then the $\mathrm{Al}_{2} \mathrm{O}_{3} / \mathrm{SiN}_{\mathrm{x}}$ stack passivation layer was deposited on both sides. Bulk lifetime can be calculated by the following two formulas [22,23].

$$
J_{o}=\frac{S_{e f f}}{q n_{i}^{2}} \times\left(N_{A}+\Delta n\right),
$$




$$
\frac{1}{\tau_{b u l k}}=\frac{1}{\tau_{e f f}}-\frac{2 S_{e f f}}{W},
$$

where $\mathrm{W}$ is the sample thickness, $S_{\text {eff }}$ is the surface recombination velocity. The $S_{\text {eff }}$ values were calculated as $9.8 \mathrm{~cm} / \mathrm{s}$ at the $10^{15} \mathrm{~cm}^{-3}$ injection level which is commonly used [22]. As a result of our calculation, the bulk lifetime was $343 \mu$ s for our wafer. The graphs in Figure 7 shows these three lifetimes of radiative, Auger and bulk recombination. If the parameter of $J_{01}$ is added to this formula, lifetime graph at high injection can be fit by using the formula below:

$$
\frac{1}{\tau_{\text {eff }}}-\frac{1}{\tau_{\text {intrinsic }}}=\frac{1}{\tau_{\text {bulk }}}+\frac{J_{01}\left(N_{A}+\Delta n\right)}{q n_{i}^{2} w} .
$$

By fitting the lifetime graph through the $J_{01}$ value, the $J_{01}$ value was calculated as $350 \mathrm{fA} / \mathrm{cm}^{2}$ for the PERC A cell and $180 \mathrm{fA} / \mathrm{cm}^{2}$ for the PERC B cell. Similar to the results of the fill factor loss analysis, the $J_{01}$ value was significantly higher for the PERC A cell.

Furthermore, we could draw the theoretical graph of $F F_{0}$ as function of $J_{02}\left(25^{\circ} \mathrm{C}\right)$ by applying the $J_{01}$ value from Figure 7 to the $J-V$ equation of double diode model without resistance Equation (16). The $J_{02}\left(25^{\circ} \mathrm{C}\right)$ of the PERC A cell was extracted by finding the point that the $F F_{0}$ from the fill factor loss analysis equal to the graph (black line in Figure 8$)$. In this way, the $J_{02}\left(25^{\circ} \mathrm{C}\right)$ of the PERC A and B cells were assessed as $27 \mathrm{nA} / \mathrm{cm}^{2}$ and $7.35 \mathrm{nA} / \mathrm{cm}^{2}$, respectively. The difference of the $J_{02}$ value was also expected from the graph in Figure 7. The graphs generally showed poor fitting results at low-level injection region. This means that the PERC A cell has poor properties of $J_{02}$ or shunt resistance because these are well known as main reasons for low lifetime of solar cells in the low-level injection region [24].

$$
J=J_{p h}-J_{01}\left[\exp \left\{\frac{q V}{n_{1} k T}\right\}-1\right]-J_{02}\left[\exp \left\{\frac{q V}{n_{2} k T}\right\}-1\right]
$$
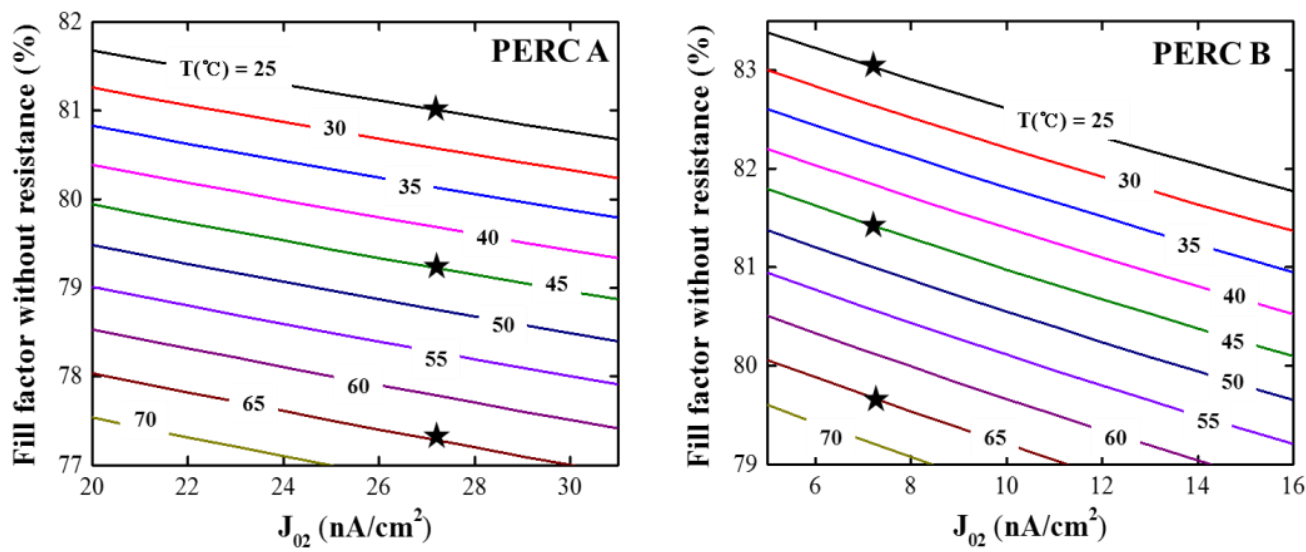

Figure 8. Theoretical calculation of $F F_{0}$ as function of the $J_{02}\left(25^{\circ} \mathrm{C}\right)$. The star marks are the $F F_{0}$ value extracted from fill factor loss analysis (Table 2).

In case of the temperature above $25{ }^{\circ} \mathrm{C}, J_{01}$ and $J_{02}$ values were calculated by using Equations (8) and (9). Through these $J_{01}$ and $J_{02}$ values, temperature conditions of the $J_{02}\left(25^{\circ} \mathrm{C}\right)-F F_{0}$ graph were extended from 30 to $70^{\circ} \mathrm{C}$. We confirmed that the $F F_{0}$ from Table 2 matched quite well with the theoretical graph. Consequently, we confirmed that the fill factor loss analysis was conducted precisely by checking the theoretically extracted $J_{01}$ and $J_{02}$ values.

\section{Conclusions}

We conducted fill factor loss analysis to investigate the temperature dependence of industrial PERC cells based on the double diode model. While analyzing the loss of fill factor for the industrial PERC A and B cells, it was confirmed that both samples showed temperature dependence of fill factor 
$\left(\sim 0.092 \% /{ }^{\circ} \mathrm{C}\right)$. However, the main parameter that dominantly contribute to temperature dependence were different depending on the initial state of the samples.

For PERC A, $J_{02}$ was the main parameter of fill factor loss in initial state $\left(25^{\circ} \mathrm{C}\right)$. However, the contribution of the $J_{01}$ to the fill factor loss increased as the temperature rose. It could be estimated that the PERC A cell has potential to improve fill factor by optimizing $J_{02}$ or shunt resistance. On the other hand, PERC B has a higher $F F_{R s}$ ratio at initial state $\left(25^{\circ} \mathrm{C}\right)$ than other parameters, but the ratio of $F F_{R s}$ reduced due to the rapid increase in the $F F_{J 01}$. Therefore, we believe that the $J_{01}$ has to be reduced for the PERC B cell by optimizing the doping process, passivation quality, and metal contacts.

In addition, we verified the accuracy of the fill factor loss analysis by comparing it to the fitting results of the injection dependent-carrier lifetime. The $J_{01}$ and $J_{02}$ values at $25{ }^{\circ} \mathrm{C}$ were extracted, and it was confirmed that the values of $F F_{0}$ obtained from the fill factor loss analysis were in good agreement with the theoretically calculated values. In conclusion, it seems very important to reduce initial fill factor loss from the $J_{01}$, because it has a high temperature dependence. In case of the $J_{02}$ and $R_{S}$, they seem less detrimental for the reduction of fill factor at an elevated temperature. Also, we confirmed that the fill factor loss analysis used in this experiment is very efficient to diagnose the temperature dependence of the solar cells, as well as their initial state.

Author Contributions: K.H.M. designed experiments, performed the experiments and wrote manuscripts; Formal analysis, T.K.; data curation, M.G.K.; investigation, H.-e.S.; review and editing, Y.K. and H.-S.L.; supervision, D.K.; project administration and supervision, S.P.; writing-review and editing and project administration, S.H.L. All authors have read and agreed to the published version of the manuscript.

Funding: This research was funded by the Ministry of Knowledge Economy, Korea (Project No. 20183030019460), and funded by the Ministry of Science, ICT \& Future Planning (Project No. 2017M1A2A2086911).

Acknowledgments: This work was conducted under the New and Renewable Energy Technology Development Program of the Korea Institute of Energy Technology Evaluation and Planning (KETEP) through a grant funded by the Ministry of Knowledge Economy, Korea (Project No. 20183030019460), and by the Technology Development Program to Solve Climate Changes of the National Research Foundation (NRF) funded by the Ministry of Science, ICT \& Future Planning (Project No. 2017M1A2A2086911).

Conflicts of Interest: The authors declare no conflict of interest. Also, the funders had no role in the design of the study; in the collection, analyses, or interpretation of data; in the writing of the manuscript, or in the decision to publish the results.

\section{References}

1. McIntosh, K. Lumps, humps and bumps: Three detrimental effects in the current-voltage curve of silicon solar cells, in: Centre for Photovoltaic Engineering. Univ. N. S. W. Aust. 2001, 171.

2. Breitenstein, O.; Rakotoniaina, J.; Al Rifai, M.H.; Werner, M. Shunt types in crystalline silicon solar cells. Prog. Photovolt. Res. Appl. 2004, 12, 529-538. [CrossRef]

3. Steingrube, S.; Breitenstein, O.; Ramspeck, K.; Glunz, S.; Schenk, A.; Altermatt, P.P. Explanation of commonly observed shunt currents in c-Si solar cells by means of recombination statistics beyond the Shockley-Read-Hall approximation. J. Appl. Phys. 2011, 110, 014515. [CrossRef]

4. Greulich, J.; Glatthaar, M.; Rein, S. Fill factor analysis of solar cells' current-voltage curves. Prog. Photovolt. Res. Appl. 2010, 18, 511-515. [CrossRef]

5. Hoenig, R.; Glatthaar, M.; Clement, F.; Greulich, J.; Wilde, J.; Biro, D. New measurement method for the investigation of space charge region recombination losses induced by the metallization of silicon solar cells. Energy Procedia 2011, 8, 694-699. [CrossRef]

6. Khanna, A.; Mueller, T.; Stangl, R.A.; Hoex, B.; Basu, P.K.; Aberle, A.G. A fill factor loss analysis method for silicon wafer solar cells. IEEE J. Photovolt. 2013, 3, 1170-1177. [CrossRef]

7. Correa-Betanzo, C.; Calleja, H.; De León-Aldaco, S. Module temperature models assessment of photovoltaic seasonal energy yield. Sustain. Energy Technol. Assess. 2018, 27, 9-16. [CrossRef]

8. Sproul, A.; Green, M. Improved value for the silicon intrinsic carrier concentration from 275 to $375 \mathrm{~K}$. J. Appl. Phys. 1991, 70, 846-854. [CrossRef]

9. The International Technology Roadmap for Photovoltaic (ITRPV). Available online: https://itrpv.vdma.org (accessed on 8 May 2020). 
10. Glunz, S.W. High-efficiency crystalline silicon solar cells. Adv. Optoelectron. 2007, 2007, 1-15. [CrossRef] [PubMed]

11. Cuevas, A.; Kerr, M.; Schmidt, J. Overview of PECVD Silicon Nitride for Solar Cells. In Proceedings of the ANZSES 2003-Destination Renewables from Research to Market, Melbourne, Austrilia, 26-29 November 2003.

12. Schmidt, J.; Merkle, A.; Bock, R.; Altermatt, P.P.; Cuevas, A.; Harder, N.-P.; Hoex, B.; Van De Sanden, R.; Kessels, E.; Brendel, R. Progress in the surface passivation of silicon solar cells. In Proceedings of the 23rd European Photovoltaic Solar Energy Conference, Valencia, Spain, 1-5 September 2008; pp. 1-5.

13. Dingemans, G.; Kessels, W. Status and prospects of Al2O3-based surface passivation schemes for silicon solar cells. J. Vac. Sci. Technol. A 2012, 30, 040802. [CrossRef]

14. Hoex, B.; Schmidt, J.; Pohl, P.; Van de Sanden, M.; Kessels, W. Silicon surface passivation by atomic layer deposited $\mathrm{Al}_{2} \mathrm{O}_{3}$. J. Appl. Phys. 2008, 104, 044903. [CrossRef]

15. Hoex, B.; Gielis, J.; Van de Sanden, M.; Kessels, W. On the c-Si surface passivation mechanism by the negative-charge-dielectric $\mathrm{Al}_{2} \mathrm{O}_{3}$. J. Appl. Phys. 2008, 104, 113703. [CrossRef]

16. Huang, H.; Lv, J.; Bao, Y.; Xuan, R.; Sun, S.; Sneck, S.; Li, S.; Modanese, C.; Savin, H.; Wang, A. 20.8\% industrial PERC solar cell: $\mathrm{ALD} \mathrm{Al}_{2} \mathrm{O}_{3}$ rear surface passivation, efficiency loss mechanisms analysis and roadmap to 24\%. Sol. Energy Mater. Sol. Cells 2017, 161, 14-30. [CrossRef]

17. Engelhart, P. Laser processing for high-efficiency silicon solar cells. In Proceedings of the Laser-based Microand Nanopackaging and Assembly III, San Jose, CA, USA, 28-29 January 2009; p. 72020S. [CrossRef]

18. Grohe, A.; Knorz, A.; Nekarda, J.; Jäger, U.; Mingirulli, N.; Preu, R. Novel laser technologies for crystalline silicon solar cell production. In Proceedings of the Laser-based Micro- and Nanopackaging and Assembly III, San Jose, CA, USA, 28-29 January 2009; p. 72020P. [CrossRef]

19. Riegel, S.; Mutter, F.; Lauermann, T.; Terheiden, B.; Hahn, G. Review on screen printed metallization on p-type silicon. Energy Procedia 2012, 21, 14-23. [CrossRef]

20. Canadian Solar Sets a $22.80 \%$ Conversion Efficiency World Record for P-Type Large Area Multi-Crystalline Silicon Solar Cell. Available online: http://investors.canadiansolar.com/news-releases?items_per_page=10\& page $=3$ (accessed on 1 June 2020).

21. Kerr, M.J.; Cuevas, A. General parameterization of Auger recombination in crystalline silicon. J. Appl. Phys. 2002, 91, 2473-2480. [CrossRef]

22. Al-Amin, M.; Grant, N.E.; Pointon, A.I.; Murphy, J.D. Iodine-Ethanol Surface Passivation for Measurement of Millisecond Carrier Lifetimes in Silicon Wafers with Different Crystallographic Orientations. Phys. Status Solidi A 2019, 216, 1900257. [CrossRef]

23. Aberle, A.G. Surface passivation of crystalline silicon solar cells: A review. Prog. Photovolt. Res. Appl. 2000, 8, 473-487. [CrossRef]

24. Lee, J.H.; Min, K.H.; Kang, M.G.; Jeong, K.T.; Lee, J.I.; Song, H.-E.; Park, S.; Park, J.-S. Efficiency characteristics of a silicon oxide passivation layer on p-type crystalline silicon solar cell at low illumination. Curr. Appl. Phys. 2019, 19, 683-689. [CrossRef]

(C) 2020 by the authors. Licensee MDPI, Basel, Switzerland. This article is an open access article distributed under the terms and conditions of the Creative Commons Attribution (CC BY) license (http://creativecommons.org/licenses/by/4.0/). 